\title{
CNRS plays down 'embryo freezing' results
}

Paris. Coverage in the media of claims by a French research group that freezing embryos affects their subsequent development - and that as a result the safety of artificial reproductive procedures in humans may have to be reassessed - have led the Centre National de la Recherche Scientifique (CNRS) to take the unusual step of issuing a statement playing down the significance of the research team's conclusions.

The research was published last month in the Proceedings of the National Academy of Sciences $(\mathbf{9 2}, 598-593 ; 1995)$ and was carried out by the Paris-based groups of Pierre Roubertoux at the Laboratory of Genetics, Neurogenetics and Behaviour, run jointly by the CNRS and the University of Paris V René Descartes, and Maurice Auroux of the Bicêtre Hospital.

In the experiments, embryos collected from two strains of mice at the two-cell stage were either directly reimplanted in host mothers (the control group) or first subjected to conservation by freezing for 15 days, and then reimplanted.

The researchers found that cryopreservation caused no "major anomalies". But they did find what they claimed to be significant differences between the two groups in several aspects of morphology and behaviour, such as the shape of the jaw and performance in activity tests.

Despite the first conclusion, the authors wrote that "substantial arguments support the hypothesis that embryo freezing can have delayed consequences". They added that this possibility "could perhaps justify a more limited use of this technique in clinical practice, until clearer conclusions about its effects in human embryos can be drawn".

Their conclusions have since received wide publicity. France's daily newspaper $L e$ Monde, for example, described the results in a front-page story entitled "The risk of freezing embryos", while a news article in Science carried a similar headline. The newspaper reports appear to have led Jean-Louis Beaumont, a physician and a member of the French parliament, to call on Edouard Balladur, the prime minister, to introduce an immediate ban on freezing human embryos.

But the CNRS has now issued a press release, written by Roubertoux, claiming that the data in the paper did not justify the publicity given to its conclusions. The release also says that the reported "statisti- cally significant differences" are similar to those usually observed between two different lines of mice.

The results, the communiqué add, show that any morphological or behavioural differences caused by freezing are small compared with those due to genetic inheritance, or "social and environmental variations".

Roubertoux claims that this interpretation of his research results is identical to that in the PNAS paper. But, although the paper does discuss the limitations of the data, it does not do so in such explicit terms as the subsequent communiqué.

Indeed, while the abstract of the PNAS paper asserts that the results "question the neutrality of artificial reproductive technologies", Roubertoux says he now acknowledges that none of the results give cause for concern about the safety of embryo freezing techniques.

Nevertheless he still maintains that the safety of freezing techniques used in artificial reproduction technologies has been neglected as a topic of study, and that further research is needed before the possibility that freezing may affect the development of embryos can be discounted. Declan Butler

\section{France keeps up pressure for maritime research policy}

Paris. The new head of France's marine research agency IFREMER promised last week to continue the efforts of his predecessor, Pierre Papon, to create a European maritime research policy.

Pierre David, at present president of the Cité des Sciences et de l'Industrie in Paris, was speaking shortly after his nomination as the new president of the agency, whose full title is the Institut Français de Recherche pour l'Exploitation de la Mer.

David is a former naval architect; he acted as adviser to the conservative prime minister Jacques Chirac on transport and urban policies during the $1970 \mathrm{~s}$, and later to the ministers for defence and transport. $\mathrm{He}$ was director of industrial policy at Aerospatiale from 1981 to 1986 , and later became president of Souriau \& Cie, a major electronics supplier to the defence industry.

The agency he is to head was created in 1984, and has responsibility for fundamental and applied marine research, as well as for large industrial and commercial activities. Its annual budget is about FFr1 billion (US\$190 million), with a staff of 1,800 .

During his six-year spell as president, Papon championed the need for a European maritime policy, and in particular developed close links with the agency's British counterpart, the Natural Environment Research Council. This has led to Franco-British cooperation, for example, on the development of optical sensors and satellite oceanography.
Papon has actively promoted ideas for a European Maritime Agency, "in which research should play a full part," and David agrees that maritime policy can "no longer be conceived at the nation-state level."

The member states of the European

\section{IMAGE UNAVAILABLE FOR COPYRIGHT REASONS}

Nautlle maintains the tradition of Jules Verne.

Union (EU) spend around ECU850 million (US\$1.05 billion) a year on marine research and technology. The research fleet includes around 40 ships - half of which are either British or French - and two research submarines, both of them French.

The economic and political stakes are high, given that marine research affects fisheries, oil exploration, shipping, transoceanic communications and the naval components of nuclear dissuasion. Moreover, according to Papon, Europe's 15,000 km of coastline means that it needs a concerted approach to problems of the environment, while marine biotechnology and the role of the oceans in climate change are likely to be key issues in the longer term.

But the EU's efforts are fragmented compared with those of the United States and Japan. At the European Commission, for

$\stackrel{\sim}{\sim}$ example, five different directorates are responsible for more than a dozen maritime programmes.

Coordination of marine research at the European level is coming about in two ways. Over the past decade, bilateral and multilateral agreements have multiplied.

The Franco-Italian project ArcoBleu, for example, aims to develop satellite tracking of shipping and coastlines to monitor pollution while last year saw the launch of L'Europe, a joint Franco-Italian 30-metre research catamaran.

At the same time the embryo of a European marine research programme has been created with the launch in 1989 of the EU's Marine Science and Technology Programme (MAST), whose current programme has a budget of ECU228 million.

The idea of a European Maritime Agency emerged from a joint meeting in Strasbourg in 1992 of the European Science Foundation and the commission, at which the heads of all the marine research agencies of the member states came together for the first time.

D. B. 